University of Nebraska - Lincoln

DigitalCommons@University of Nebraska - Lincoln

October 1999

Introduction to International Perspectives on Therapeutic Jurisprudence

\author{
Alan Tomkins \\ University of Nebraska, atomkins@nebraska.edu \\ David Carson \\ University of Southampton
}

Follow this and additional works at: https://digitalcommons.unl.edu/publicpolicytomkins

Part of the Public Policy Commons

Tomkins, Alan and Carson, David, "Introduction to International Perspectives on Therapeutic Jurisprudence" (1999). Alan Tomkins Publications. 4.

https://digitalcommons.unl.edu/publicpolicytomkins/4

This Article is brought to you for free and open access by the Public Policy Center, University of Nebraska at DigitalCommons@University of Nebraska - Lincoln. It has been accepted for inclusion in Alan Tomkins Publications by an authorized administrator of DigitalCommons@University of Nebraska - Lincoln. 


\section{Introduction to International Perspectives on Therapeutic Jurisprudence}

Therapeutic Jurisprudence (TJ), a concept first conceived by law professors David Wexler (University of Puerto Rico and University of Arizona) and Bruce Winick (University of Miami) only a little more than a decade ago, has emerged as the leading conceptual perspective in the mental health law field. Indeed, a LEXIS search reveals well over 150 articles on, or citing to, therapeutic jurisprudence in American law review publications in the past decade (terms used were "therapeutic w/5 jurisprudence w/25 Wexler or Winick").

Although initially a notion that provided an alternative to the traditional "rights" approach to thinking about mental health law problems in the US, TJ has evolved beyond just a mental health conception and expanded way beyond the borders of the USA. For example, under Wexler's guidance, the University of Puerto Rico School of Law has recently created an International Network on Therapeutic Jurisprudence, and the school's law review, Revista Juridica Universidad de Puerto Rico, has been regularly publishing TJ articles for the past several years. In July 1998, the University of Southampton and the Behavioral Science and Law Network sponsored the first International Conference on Therapeutic Jurisprudence in Winchester, England, a conference coordinated by one of us (DC) with considerable assistance from Wexler and Winick. Moreover, TJ was a major theme at the international conference on psychology and law held in Dublin in July 1999, and another international TJ conference is scheduled for Cincinnati, Ohio, in 2001.

It should not have surprised us, then, to find that our solicitation of manuscripts for this special issue yielded more publishable manuscripts that could be published in a single issue of Behavioral Sciences \& the Law. Rather than reject publishable manuscripts, we decided to publish some in this special issue and publish the rest next year as part of a second special on Therapeutic Jurisprudence. Taken together, the articles in the two issues reflect the kinds of rich and varied work that is being done under the TJ umbrella.

The current issue begins with two philosophical considerations of TJ. American law professors Ken Kress ("Therapeutic Jurisprudence and the Resolution of Value Conflicts: What We Can Realistically Expect, in Practice, From Theory") and Robert Schopp ("Therapeutic Jurisdiction: Integrated Inquiry and Instrumental Prescriptions"). These are followed by an article by another law professor (Canadian-born and educated, but teaching in the US), James Cooper ("State of the Nation: Therapeutic Jurisprudence and the Evolution of the Right of Self-Determination in International Law") who uses TJ to examine international law issues (and philosophical considerations). Special issue co-editor, and reader in law and behavioral sciences at the University of Southampton, David Carson's article is next ("From Status to Contract: 
A Future for Mental Health Law"). Carson's article is followed by the only empirical work included in this issue, a restorative justice/therapeutic jurisprudence examination by Australian psychologist Adelma Hills and psychologist/lawyer Donald Thomson ("Should Victim Impact Influence Sentences? Understanding the Community's Justice Reasoning"). The issue concludes with three reviews/essays of Wexler and Winick's most recent edited TJ compilation, Law in a Therapeutic Key (1996); the reviews/ essays are authored by an American law professor, Thomas Hafemeister, one of the US's leading forensic psychologists, Kirk Heilbrun, and an American-born law professor teaching clinical law in England, Kate Diesfeld.

Readers will note there are differences in spelling and the style across the articles. This means, for example, that articles from England use "behavioural" whereas articles from the US use "behavioral". As part of our internationalization efforts, $B S \& L$ intends to present articles in the style used by authors rather than change to conform to US practices.

Finally, thanks are due to David Wexler and Bruce Winick for their help with the TJ special issues. Not only were they instrumental in the success of the Winchester conference, which was the conference at which many of the TJ works were first presented, but they also helped recruit additional submissions for the TJ issues. Their ideas, insights, and contributions have been greatly appreciated, as is their generosity of time and spirit.

$$
\begin{array}{r}
\text { Alan J. Tomkins, J.D., Ph.D., and David Carson, LL.B, } \\
\text { Special Issue Editors }
\end{array}
$$

Published in Behavioral Sciences and the Law 17 (1999), pp. 553-554. Copyright (C) 1999 John Wiley \& Sons, Ltd. Used by permission. 